\title{
PENGARUH LINGKUNGAN SEKOLAH TERHADAP MINAT MELANJUTKAN KEJENJANG SEKOLAH MENENGAH ATAS
}

\author{
KUSWORO $^{1)}$, SHOCHWATUL ISLAMIYAH ${ }^{2)}$ \\ ${ }^{1)}$ Dosen Pendidikan Ekonomi Universitas Pamulang \\ ${ }^{2)}$ Mahasiswa Pendidikan Ekonomi Universitas Pamulang \\ dosen01674@unpam.ac.id ${ }^{1}$, shochwa@gmail.com ${ }^{2}$
}

\begin{abstract}
ABSTRAK
Penelitian ini bertujuan untuk menganalisis pengaruh lingkungan sekolah terhadap minat melanjutkan kejenjang sekolah menengah atas pada siswa. Penelitian ini menggunakan metode penelitian kuantitatif. Teknik pengambilan sampel dalam penelitian ini menggunakan simple random sampling dengan pengumpulan data menggunakan teknik observasi, wawancara dan dokumentasi. Hasil penelitian menunjukkan bahwa Lingkungan Sekolah mempengaruhi minat melanjutkan kejenjang SMA pada siswa kelas IX SMP Islam Daar El-Arqam tahun ajaran 2018/2019 dapat dilihat dari Uji t, dengan nilai t hitung yang diperoleh dari variabel bebas Lingkungan Sekolah yaitu sebesar 0,000 yang berarti lebih kecil dari 0,05 dimana dengan pedoman hipotesis ialah jika profitabilitas/signifikan <0,05 maka Ho ditolak dan Ha diterima dan jika profitabilitas/ signifikan $>0,05$ maka Ho diterima dan Ho ditolak. Jika dilihat dari hasil yang diperoleh, maka $0,000<0,05$ yang berarti Ho ditolak dan Ha diterima. Dapat disimpulkan variabel bebas yaitu Lingkungan Sekolah berpengaruh terhadap minat melanjutkan pendidikan ke SMA.
\end{abstract}

Kata Kunci : Lingkungan Sekolah, Minat.

\section{PENDAHULUAN}

Bidang pendidikan merupakan salah satu sektor yang ikut menjadi pertimbangan pemerintah untuk mencapai globalisasi. Pendidikan merupakan sesuatu yang penting bagi setiap negara, karena dengan pendidikan suatu negara dapat menghasilkan sumber daya manusia yang diharapkan mampu meningkatkan kualitas suatu bangsa. Oleh karenanya kemajuan suatu bangsa dapat diukur dari kemajuan pedidikannya.

UU No.20 Tahun 2003 tentang suatu sistem pendidikan nasional pada pasal 13 ayat 1 menyatakan bahwa jalur pendidikan terbagi menjadi tiga mascam yaitu tiga pendidikan formal, nonformal dan informal yang dapat saling melengkapi dan memperkaya. Pendidikan formal meliputi Sekolah Dasar (SD) atau yang sederajat dan Sekolah Menengah Pertama (SMP) 
dan Sekolah Menengah Atas (SMA) atau sederajat dan pendidikan tinggi yang diselenggarakan di Perguruan tinggi.

Pencapaian tujuan pendidikan, telah dilakukan pemerintah diantaranya wajib belajar pendidikan dasar 9 tahun. Wajib belajar jalur pendidikan dasar 9 tahun adalah program dari pemerintah untuk menjawab kebutuhan dan tantangan zaman.

Pemerintah mewajibkan semua warga Indonesia wajib sekolah dari SD atau sederajat, SMP atau sederajat. Namun di era modern dan globalisasi saat ini pendidikan dasar 9 tahun tidak cukup untuk bisa bersaing dalam dunia kerja, walaupun pemerintah hanya mewajibkan belajar 9 tahun tetapi dengan era modern dan globalisasi saat ini melanjutkan SMA atau sederajat adalah hal yang harus dilakukan untuk dapat bersaing dalam dunia kerja.

Tabel 1.1 APK SM (Termasuk Madrasah dan Sederajat) Tahun 2016/2017

\begin{tabular}{|l|l|l|l|l|l|l|}
\hline $\begin{array}{l}\text { Nama } \\
\text { Provinsi }\end{array}$ & Kabupaten/kota & $\begin{array}{l}\text { Penduduk } \\
\text { usia 16-18 } \\
\text { thn }\end{array}$ & $\begin{array}{l}\text { Jumlah } \\
\text { Siswa } \\
\text { Siswa } \\
\text { usia 16- } \\
\mathbf{1 8} \text { thn }\end{array}$ & $\begin{array}{l}\text { Jumlah } \\
\text { APK }\end{array}$ & APM \\
\hline Banten & Kab. Pandeglang & 74.669 & 51.732 & 39.740 & 69,28 & 53,22 \\
\hline Banten & Kab. Lebak & 64.548 & 47.407 & 36.065 & 73,44 & 55,87 \\
\hline Banten & Kab. Tangerang & $\mathbf{1 7 5 . 8 4 5}$ & $\mathbf{1 2 4 . 7 7 9}$ & $\mathbf{9 2 . 4 8 6}$ & $\mathbf{7 0 , 9 6}$ & $\mathbf{5 2 , 6 0}$ \\
\hline Banten & Kab. Serang & 91.896 & 62.040 & 47.118 & 67,51 & 51,27 \\
\hline Banten & Kab. Cilegon & 22.916 & 22.610 & 17.266 & 98,66 & 75,34 \\
\hline Banten & Kota Tangerang & 91.320 & 81.799 & 59.372 & 89,57 & 65,02 \\
\hline Banten & Kota Serang & 40.268 & 37.163 & 28.816 & 92,29 & 71,56 \\
\hline Banten & $\begin{array}{l}\text { Kota Tangerang } \\
\text { Selatan }\end{array}$ & 73.738 & 60.459 & 43.388 & 81,99 & 58,84 \\
& & & & & \\
\hline
\end{tabular}

Sumber: Dari kementrian pendidikan dan kebudayaan pusat data dan statistic pendidikan dan kebudayaan tahaun 2017 
Menurut Tabel $1.1 \mathrm{di}$ atas rincian masalah pada wilayah Kabupaten Tangerang, menurut usianya siswa dengan usia 16-18 tahun adalah siswa yang mengenyam pendidikan sekolah menengah atas. Menurut data dari Kementerian Pendidikan dan Kebudayaan Pusat Data dan Statistik Pendidikan Dan Kebudayaan tahun 2017 penduduk Provinsi Banten Kabupaten Tangerang dengan usia 16-18 tahun berjumlah 175.845 dengan Angka Partisipasi Murni (APM) 52,60 berarti penduduk dengan usia 16-18 tahun hanya 52,60 yang melanjutkan kejenjang Sekolah Menengah Atas sisanya 47,4 putus sekolah atau sedang mengenyam pendidikan pada tingkat lain. Sedangkan untuk APK berjumlah 70,96 berarti penduduk yang melanjutkan kejenjang pendidikan tanpa melihat usia berjumlah 70,96 sedangkan sisanya 29,04 tidak melanjutkan kejenjang sekolah menengah atas.

Dari Tabel 1.1 di atas APK Kabupaten Lebak 73,44 dan APM 55,87 dan Kabupaten Tangerang tingkat APK dan APMnya lebih rendah yaitu APK 70,96 dan APM 52,60. Padahal menurut data BPS pada tahun 2017 Kabupaten Lebak menempati tingkat kemiskinan dengan angka 8,64\%,sedangkan Kabupaten Tangerang lebih rendah dengan angka 5,39\%. Kabupaten Tangerang adalah wilayah yang dekat dengan ibu kota dan disebut sebagi kota industri karena banyak industri yang berdiri disana, seharusnya minat untuk melanjutkan kejenjang SMA lebih tinggi dibandingkan Kabupaten Lebak.Namun kenyataannya sumber daya manusianya masih banyak yang tidak melanjutkan kejenjang sekolah menengah atas.

Mengingat wajib belajar sekolah hanya 9 tahun menyebabkan masih ada anak yang tidak melanjutkan ke tingkat jenjang mengah karena berbagai faktor. Oleh karena itu minat siswa untuk melanjutkan pendidikan ke SMA atau sederajat perlu kembangkan pada anak SMP sejak awal. Minat melanjutkan ke SMA atau sederajat ialah suatu kecenderungan yang mengarahkan siswa untuk melanjutkan ke sekolah SMA.

Minat tidak akan ada dengan sendirinya tetapi ada faktor-faktor lain yang bisa menumbuhkan minat itu sendiri. Sadirman dalam (Aryanto, 2015:3) bahwa, "minat itu tidak muncul secara tiba-tiba / spontan, namun muncul dari adanya partisipasi atau keikutsertaan, pengalaman, kebiasaan pada proses waktu belajar dan bekerja".

Menurut Slameto (2010:180) bahwa minat diartikan sebagai suatu rasa lebih suka dan rasa ketertarikan pada suatu hal atau aktivitas, tanpa ada yang menyuruh. Minat pada dasarnya adalah penerimaan akan sesuatu hubungan antara diri sendiri dengan sesuatu di luar diri. Dan menurut 
Sardiman (2011:76) menjelaskan minat adalah suatu kondisi yang terjadi apabila seseorang melihat cirriciri atau arti sementara situasi yang dihubungkan dengan keinginankeinginan atau kebutuhankebutuhannya sendiri. Oleh karena itu, apa yang dilihat seseorang sudah tentu akan membangkitkan minatnya sejauh apa yang dilihat itu mempunyai hubungan dengan kepentingannya sendiri.

Berdasarkan pada beberapa pendapat tersebut dapat dikatakan bahwa minat adalah kecenderungan diri dalam individu untuk tertarik pada suatu objek atau menyenangi sesuatu objek, semakin kuat atau dekat hubungan tersebut maka semakin besar minatnya. Minat biasanya ditunjukkan melalui pernyataan yang menunjukkan lebih menyukai suatu hal dan dapat dinyatakan juga dalam bentuk partisipasi dalam aktivitas yang diminatinya. Jadi, dapat dikatakan bahwa indikator dari minat antara lain adanya perasaan senang, adanya keinginan, adanya perhatian, adanya ketertarikan, adanya kebutuhan, adanya harapan, adanya dorongan dan kemauan.

Minat dipengaruhi oleh banyak hal/faktor, baik dari luar maupun faktor dari dalam siswa. Faktor dari dalam siswa seperti motivasi belajar, bakat, keadaan fisik, dan sikap. Sedangkan faktor dari luar salah satunya adalah lingkungan sekolah.
Sekolah merupakan salah satu jenis jenis lembaga pendidikan formal untuk memberikan siswa wawasan dan pengetahuan agar bisa mengembangkan potensinya dan bakat yang dimilikinya, baik dari aspek moral, spiritual, intelektual, emosional, ataupun sosial kegiatan pembelajara di sekolah melibatkan berbagai komponen atau unsur-unsur diantaranya sarana prasarana belajar yang ada, sumber-sumber belajar, media belajar, media belajar dan seterusnya yang merupakan lingkungan fisik pada sekolah. Lingkungan sosial berkaitan dengan hubungan siswa dengan teman lainnya, siswa dengan guru serta staf sekolah yang lain.

Tulus Tuu (2004:1) lingkungan sekolah dipahami sebagai lembaga pendidikan formal, dimana tempat inilah kegiatan belajar mengajar berlangsung, ilmu pengetahuan diajarkan dan dikembangkan kepada peserta didik.

Menurut Gunawan (2002:57) menyatakan bahwa lingkungan sekolah merupakan lingkungan kedua bagi bagi anak dan merupakan lingkungan pendidikan formal yang membantu orang tua dalam mengemban tanggung jawab pendidikan. Pendidikan yang diberikan didalam pendidikan di sekolah berupa pembentukkan nilainilai, pengetahuan, keterampilan dan sikap terhadap mata pelajaran atau bidang studi. 
Dapat dikatakan bahwa lingkungan sekolah adalah seluruh kompenen atau bagian yang terdapat di sekitar lingkungan sekolah, yang mana seluruh kompenen dan bagian tersebut ikut berpengaruh dan menunjang dalam proses pencapaian tujuan pendidikan yang ada di sekolah. Seperti dalam menyelenggarakan kegiatan - kegiatan pembelajaran secara sistematis, berencana, sengaja, dan terarah yang dilakukan pendidik secara profesional dengan program yang dituangkan dalam kurikulum.

Adapun fungsi sekolah menurut Nasution (2011:14), yaitu sekolah mempersiapkan anak untuk suatu pekerjaan, sekolah memberikan keterampilan dasar, sekolah membuka kesempatan memperbaiki nasib, sekolah menyediakan tenaga pembangunan, sekolah mebantu memecahkan masalah-masalah sosial, sekolah menstramisi kebudayaan, sekolah membentuk manusia yang sosial, sekolah meruapakan alat mentransformasi kebudayaan.

Tabel 1.2 Jumlah Siswa yang Melanjutkan Studi Kejenjang Sekolah Menengah Atas dan Sederajat Lainnya

\begin{tabular}{|l|c|c|c|c|}
\hline No & Tahun Ajaran & Jumlah Lulusan & $\begin{array}{l}\text { Jumlah siswa yang } \\
\text { melanjutkan ke SMA } \\
\text { dan sederajat lainnya }\end{array}$ & $\begin{array}{l}\text { Persentase siswa yang } \\
\text { melanjutkan ke SMA } \\
\text { dan sederajat lainnya }\end{array}$ \\
\hline 1 & 2016 & 184 & 101 & $54,8 \%$ \\
\hline 2 & 2017 & 221 & 116 & $52,5 \%$ \\
\hline 3 & 2018 & 238 & 118 & $50,8 \%$ \\
\hline
\end{tabular}

Sumber: SMP Islam Daar El-Arqaam (data diolah oleh peneliti, 2019)

Pada tabel 1.2 di atas dapat diketahui pada tahun 2016, 2017, dan 2018 jumlah siwa yang melanjutkan studi ke SMA atau sederajat lainnya membentuk karakter siswa. Sarana dan prasarana yang memadai akan memudahkan siswa dalam proses pembelajaran, sehingga siswa akan senang belajar. Hubungan sosial yang baik antara siswa dengan temantemannya, guru, dan warga sekolah lain akan membuat siswa merasa nyaman berada di sekolah. Sehingga siswa akan merasa bahwa sekolah adalah rumah ke duanya maka minta siswa untuk sekolah pun tinggi.

SMP ISLAM DAAR ELARQAM merupakan salah satu Sekolah Menengah Pertama (SMP) islam yang beralamat di Jl. Raya Mauk km.12, kp. Lor Rt.13/004 Ds.Tegal kunir Lor kec.Mauk Kab.Tangerang. Berdasarkan pengamatan yang peneliti peroleh lulusan SMP Islam Daar ELarqam mempunyai minat untuk melnjutkan ke pendidikan kejenjang sekolah menengah atas (SMA) hanya sebagian dari keseluruhan lulusan. Hal ini dapat dilihat pada Tabel 1.2. 
minat pada siswa untuk melanjutkan sekolah kejenjang yang lebih tinggi bahkan setiap tahunnya mengalami penurunan jumlah siswa yang melanjutkan kejenjang Sekolah Menengah Atas.

Berdasarkan masalah yang dikemukakan di atas, peneliti tertarik untuk melakukan penelitian secara teliti dengan judul "Pengaruh Lingkungan Sekolah terhadap Minat Melanjutkan kejenjang Sekolah Menengah Atas pada Siswa Kelas IX SMP Islam Daar-EL Arqam Tahun Ajaran 2018/2019".

\section{METODE PENELITIAN}

Penelitian ini menggunakan metode kuantitatif. Penelitian kuantitatif adalah jenis penelitian yang tidak terlalu mengacu dengan kedalaman suatu data, Penelitian kuantitatif tidak begitu mementingkan pada seberapa dalam data yang ada, yang terpenting bisa di pakai untuk merekam data sebanyak mungkin dari populasi yang ada, sehingga dapat menemukan hasil yang dicari dari suatu penelitian.

Menurut Sugiyono (2011:7) mengemukakan pendapatnya tentang metode kuantitatif, metode kuntitatif sudah cukup lama digunakan sehingga sudah mentradisi sebagai metode penelitian sehingga dinamakan motede tradisional. Metode ini berlandaskan pada filsafat positivism sehingga disebut sebagai metode positivisik. Populasi pada penelitian ini yaitu seluruh siswa SMP kelas IX pada SMP Islam Daar ElArqam.Berdasarkan data dari SMP Islam Daar El-Arqam jumlah siswa kelas IX pada tahun ajaran 2018/2019 adalah 176 siswa. Sedangkan untuk sampel melalu perhitungan dengan menggunakan populasi finite adalah sebanyak 139 siswa.

\section{HASIL DAN PEMBAHASAN}

\section{Uji Asumsi klasik}

a) Uji normalitas

Berikut disajikan dalam Tabel 1.3. berkaitan dengan hasil uji normalitas

\begin{tabular}{|l|r|r|r|r|r|c|}
\hline \multicolumn{7}{|c|}{ Tabel 1.3 Uji Normalitas Lingkungan Sekolah } \\
Tests of Normality \\
\hline & \multicolumn{2}{|c|}{ Kolmogorov-Smirnov } & \multicolumn{3}{c|}{ Shapiro-Wilk } \\
\cline { 2 - 7 } & Statistic & \multicolumn{1}{c|}{ df } & \multicolumn{1}{c|}{ Sig. } & Statistic & \multicolumn{1}{c|}{ df } & \multicolumn{1}{c|}{ Sig. } \\
\hline \multirow{2}{*}{ lingkungan sekolah } & $\mathbf{0 , 0 6 9}$ & 139 & $\mathbf{0 , 0 9 9}$ & $\mathbf{0 , 9 8 4}$ & $\mathbf{1 3 9}$ & $\mathbf{0 , 0 9 8}$ \\
\hline Minat & & & & & & \\
\hline Unstandardized Residual & $\mathbf{0 , 0 7 1}$ & $\mathbf{1 3 9}$ & $\mathbf{0 , 0 8 5}$ & $\mathbf{0 , 9 8 5}$ & $\mathbf{1 3 9}$ & $\mathbf{0 , 1 3 6}$ \\
\hline
\end{tabular}

Sumber : Hasil olahan SPSS 24 
Berdasarkan hasil yang diperoleh taraf signifikan Lingkungan Sekolah sebesar 0,099 yang berarti lebih besar dari 0,05 yang berarti Ho diterima dan $\mathrm{H} 1$ ditolak, maka dapat dikatakan variabel lingkungan Sekolah berdistribusi normal.

Tabel 1.4 Uji Linieritas Lingkungan Sekolah Terhadap Minat

\begin{tabular}{|c|c|c|c|c|c|c|c|}
\hline \multicolumn{8}{|c|}{ ANOVA Table } \\
\hline & & & $\begin{array}{l}\text { Sum of } \\
\text { Squares }\end{array}$ & Df & $\begin{array}{l}\text { Mean } \\
\text { Square }\end{array}$ & $\mathrm{F}$ & Sig. \\
\hline \multirow{5}{*}{$\begin{array}{l}\text { Minat* } \\
\text { Lingkungan } \\
\text { Sekolah }\end{array}$} & \multirow{3}{*}{$\begin{array}{l}\text { Between } \\
\text { Groups }\end{array}$} & (Combined) & 2151,250 & 19 & 113,224 & 120,998 & 0,000 \\
\hline & & Linearity & 2132,327 & 1 & 2132,327 & 2278,744 & 0,000 \\
\hline & & $\begin{array}{l}\text { Deviation } \\
\text { from } \\
\text { Linearity }\end{array}$ & 18,923 & 18 & 1,051 & 1,123 & 0,338 \\
\hline & \multicolumn{2}{|c|}{ Within Groups } & 111,354 & 119 & 0,936 & & \\
\hline & \multicolumn{2}{|l|}{ Total } & 2262,604 & 138 & & & \\
\hline
\end{tabular}

Sumber : Hasil olahan SPSS 24

Berdasarkan hasil yang diperoleh taraf sig Lingkungan Keluaraga (X1) sebesar 0.000 yang berarti lebih kecil dari 0,05 . $0,000<0,05 \mathrm{H}_{1}$ diterima yang berarti terdapat hubungan yang linier antar dua variabel bebas. Maka dapat dikatakan sebaran data lingkungan sekolah berdistribusi normal.

c) Uji t

Hasil pengujian dapat dilihat pada tabel Coefficients seperti Tabel 1.5 di bawah ini. Dengan aplikasi b) Uji linieritas

Berikut disajikan Tabel 1.4 hasil uji linieritas variabel lingkungan sekolah terhadap minat siswa melanjutkan ke perguruan tinggi.

\section{Tabel 1.5 Hasil Uji t}

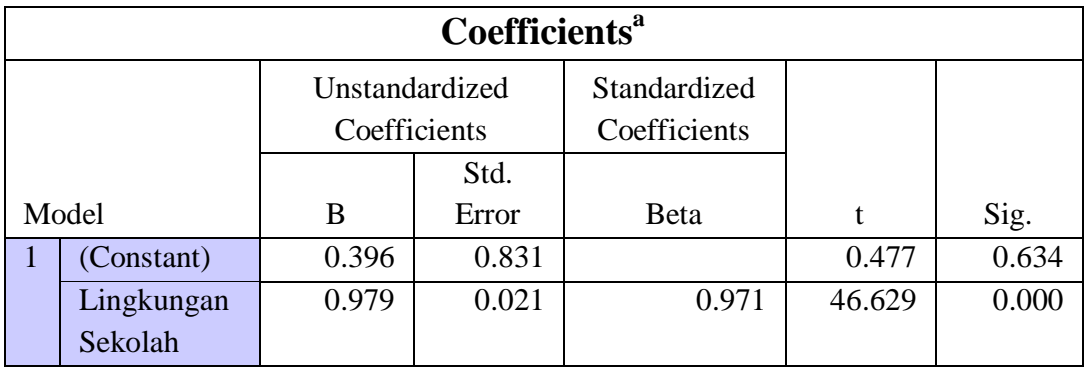

a. Dependent Variable: Minat

Berdasarkan Tabel 1.5 di atas, dapat dilihat bahwa nilai signifikansi a adalah 0,000 yang berarti lebih kecil
SPSS, maka uji $\mathrm{t}$ dapat dengan mudah diperoleh hasilnya. Jika nilai sig a lebih kecil dari tingkat kesalahan (alpha) 0,05 maka dapat dikatakan bahwa variabel bebas berpengaruh signifikan terhadap variabel terikatnya. Sedangkan nilai sig $a$ hitung lebih besar dari tingkat kesalahan 0,05 maka dapat dikatakan bahwa variabel bebas tidak berpengaruh signifikan terhadap variabel terikatnya.

dari 0,05 maka dapat dikatakan Lingkungan Sekolah berpengaruh terhadap minat melanjutkan SMA. 
Sebagai pedoman Hipotesis, jika siginifikan $<0.05$ maka Ho ditolak dan Ha diterima dan jika Signifikan $>0,05$ maka Ho diterima dan Ha ditolak.

Berdasarkan teori menurut Gunawan (2002:57) menyatakan lingkungan sekolah adalah lingkungan kedua bagi anak dan merupakan lingkungan pendidikan formal yang membantu orang tua dalam mengemban tanggung jawab pendidikan. Pendidikan yang diterima di sekolah berupa pembentukan nilai-nilai, pengetahuan, keterampilan dan sikap terhadap mata pelajaran atau bidang studi. Berdasarkan teori tersebut dan berdasarkan angket yang telah diujikan mengenai Lingkungan Sekolah menyatakan bahwa Lingkungan Sekolah membentuk nilai-nilai yang ada pada siswa, wadah dalam mencari ilmu dan mengasah bakat siswa.

Berdasarkan hasil pengukuran variabel Lingkungan Sekolah dengan skor tertinggi 37 dan skor terendah 14 dengan rata-rata 3,869. Hal tersebut terjadi karena Lingkungan Sekolah berperan penting dalam pembentukan karakter, pola pikir, dan dalam pengambilan keputusan. Lingkungan Sekolah mempengaruhi Minat siswa melanjutkan ke jenjang SMA dengan berbagai indikator didalamnya.

\section{KESIMPULAN}

Berdasarkan hasil analisa data, dapat disimpulkan bahwa Lingkungan Sekolah mempengaruhi minat melanjutkan kejenjang SMA pada siswa kelas IX SMP Islam Daar El-Arqam tahun ajaran 2018/2019 dapat dilihat dari Uji t, dengan nilai t hitung yang diperoleh dari variabel bebas Lingkungan Sekolah yaitu sebesar 0,000 yang berarti lebih kecil dari 0,05 dimana dengan pedoman hipotesis ialah jika profitabilitas/signifikan $<0,05$ maka Ho ditolak dan Ha diterima dan jika profitabilitas/ signifikan > 0,05 maka Ho diterima dan Ho ditolak. Jika dilihat dari hasil yang diperoleh, maka $0,000<$ 0,05 yang berarti Ho ditolak dan $\mathrm{Ha}$ diterima. Dapat disimpulkan variabel bebas yaitu Lingkungan Sekolah berpengaruh terhadap minat melanjutkan pendidikan ke SMA.

\section{REFERENSI}

A.M. Sardiman. 2011. Interaksi dan Motivasi Belajar Mengajar. Jakarta : Rajawali Press.

Aryanto, Elfin Ardi. 2015. Pengaruh Motivasi Belajar Dan Pendapatan Orang Tua Terhadap Minat Siswa Kelas XI SMAN Jogonalan Tinggi Untuk Melanjutkan Ke Jenjang Perguruan Tinggi Tahun Ajaran 2015/2016.Skripsi tidak diterbitkan. Universitas Yogyakarta.

Gunawan, Ary. 2002. Sosiologi Pendidikan. Jakarta: Rineka Cipta.

Slameto. 2010. Belajar dan Faktor Faktor yang Mempengaruhinya. Jakarta: PT. Rineka Cipta.

Sugiyono. 2011. Metode Penelitian Administrasi: Dilengkapi Dengan Metode R\&D. Bandung : Alfabeta. Tu'u, Tulus, 2004, Peran Disipiln pada perilaku dan prestasi Siswa, Jakarta: Gramedia widiasarana. 
Undang-Undang Nomor 20 Tahun 2003

Pasal 13 ayat 1 Tentang Sistem

Pendidikan Nasional.

Nasution. S. 2011. Berbagai Pendekatan

Dalam Proses Belajar Mengajar.

Jakarta : PT Bumi Aksara. 